“Монгол Улс НҮБ-д - 50 жил” эрдэм шинжилгээний бага хурал

\title{
НУБ-ЫН ҮЙЛ АЖИЛЛАГААН ДАХЬ МОНГОЛ УЛСЫН ОРОЛЦОО: ҮР ДУН БА ЦААШИД ТАВИХ ЗОРИЛТУУД
}

Г.Баттунгалаг*

Эрхэм хүндэт зочид оо,

Юуны өмнө Монгол Улс НҮБ-д элссэний 50 жилийн ойн баярын мэндчилгээ дэвшүүлж, Монгол НҮБ-ын хамтын ажиллагааг өргөжүүлэн хөгжүүлэх амаргүй хийгээд эрхэм үйлсэд хүчээ дайчлан, хувь нэмрээ оруулж ирсэн Та бүхэнд талархал илэрхийлье.

Монгол Улсын аюулгүй байдал, үндэсний язгуур ашиг сонирхлыг олон улсын эрх зүйн хүрээнд улс төр-дипломатын аргаaр ханган хамгаaлах нь гадаад бодлогын тэргүүлэх зорилт мөн. Түүнийг хэрэгжүүлэх, дэлхий нийтийн тулгамдсан асуудлуудыг шийдвэрлэхэд өөрийн улсын хувь нэмрээ оруулах, байр сууриа бэхжүүлэх, дуу хоолойгоо сонсгож байхад олон улсын байгууллагууд,нэн ялангуяа, Нэгдсэн Үндэсний Байгууллага чухал үүрэгтэй.

НҮБ- олон улсын хамтын нийгэмлэг дэх манай улсын оролцоо нь олон улсын энх тайван, аюулгүй байдлыг хангах, энхийг сахиулах, зэвсэг хураaх асуудлаас эхлээд ардчилал, боловсрол, эмэгтэйчүүдийн аж байдлыг сайжруулах, хоршооллыг дэмжих, далайд гарцгүй хөгжиж буй орнуудын онцгой хэрэгцээ шаардлагыг хангах, уур амьсгалын өөрчлөлтөд дасан зохицох зэрэг өргөн хүрээг хамарч байна.

Өнгөрсөн хугацаанд манай улс НҮБ, түүний системийн байгууллагуудын үйл ажиллагаанд идэвхтэй оролцож, олон улсын хамтын нийгэмлэгийн өмнө тавигдаж буй тулгамдсан асуудлаар байр сууриа илэрхийлэх, тодорхой зарим асуудлаар санал санаачилга гарган тогтоол, шийдвэр батлуулах, гаргасан шийдвэрийг хэрэгжүүлэхэд оролцож хамтран ажиллахыг чухалчилж ирсэн. 
Манай улс НҮБ-д гишүүнээр элссэнээсээ хойш Ерөнхий Ассамблейд 20 орчим асуудлаар нийт 70 гаруй тогтоол санаачлан батлуулсан байна. Тухайлбал,“Их Монгол Улс байгуулагдсаны 800 жилийн ой”, “Нийгмийн хөгжилд хоршооллын гүйцэтгэх үүрэг”, “Хөдөөгийн эмэгтэйчүүдийн аж байдлыг сайжруулах”, “Бичигтэн болох НҮБ-ын 10 жил”, “Ардчиллыг шинээр болон сэргээн тогтоох чиглэлээр Засгийн газраас тавьж буй хүч чармайлтад НҮБ-ын системийн зүгээс үзүүлэх дэмжлэг“, “Монгол Улсын олон улсын аюулгүй байдал, цөмийн зэвсэггүй статус", далайд гарцгүй хөгжиж буй орнуудын онцгой хэрэгцээ шаардлагыг хангах тухай зэрэг тогтоолыг дурдаж болно. Тэдгээр тогтоол, шийдвэр нь НҮБ, түүний системийн байгууллагууд, гишүүн орнуудын анхаарал, хүч чармайлтыг тухайн асуудалд хандуулж, шийдвэрлэхэд чухал ач холбогдолтой байсан.

Нөгөөтэйгүүр, эдгээр нь манай улсын аюулгүй байдлыг бэхжүүлэх, нийгэм, эдийн засгийн тулгамдсан асуудлуудыг шийдвэрлэх үйл хэрэгт ихээхэн тус дэм болж ирснийг онцлон тэмдэглэх нь зүйтэй болов уу. Тухайлбал, цөмийн зэвсэггүй статусын тухай тогтоолыг Ерөнхий Ассамблейгаар батлуулснаар уг статусаа олон улсын хэмжээнд баталгаажуулсан. Улмаар манай цөмийн зэвсэггүй статусыг дэмжиж, сайшаасан заалт нийт 20 гаруй олон талт хамтын ажиллагааны баримт бичиг, хоёр талын хамтарсан мэдэгдэлд тусгагдаад байна.

НҮБ-ын энхийг сахиулах ажиллагаанд хувь нэмрээ оруулах нь манай улсын гадаад бодлогын тэргүүлэх чиглэлийн нэг мөн. 1999 онд НҮБ-тай байгуулсан Харилцан ойлголцлын санамж бичгийн дагуу Монгол Улсын Зэсвэгт хүчний бие бүрэлдэхүүнийг бэлтгэж, халуун цэгүүдэд илгээж ирсэн бөгөөд манай энхийг сахиулагчид хүлээсэн үүргээ нэр төртэй биелүүлж байна.

Манай улсын цэрэг, дайчид, энхийг сахиулагчид өөрийн улсын нэр хүндийг олон улсын тавцанд өргөж, Үүргээ амжилттай биелүүлж байгааг олон улсын хамтын нийгэмлэг, Нэгдсэн Үндэстний Байгууллагаас сайшааж байдаг. Түүний нэг тод жишээ нь өнгөрсөн 3 дугаар сард НҮБ-ын Аюулгүйн Зөвлөлөөс баталсан S/Res/1971 (2011) тоот тогтоолд Сьерра Леонед үүрэг гүйцэтгэсэн Монгол Улсын Зэвсэгт хүчний цэргийн бие бүрэлдэхүүнийг өндрөөр үнэлж, олон улсын энх тайван, аюлгүй байдлыг хангах НҮБ-ын хүч чармайлтад бодит хувь нэмрээ оруулсан гэж дүгнэсэн.

Энэ хугацаанд манай улс олон улсын 240 орчим гэрээ, конвенцид нэгдэн орсон байна. Тэдгээр гэрээ, конвенци болон Ерөнхий Ассамблей, Аюулгүйн Зөвлөлийн тогтоолуудыг хэрэгжүүлэх хүрээнд НҮБ-ын гишүүн орнуудтай үр дүнтэй хамтран ажиллахад 
чухалчилан анхаарч ирсэн. Жишээ нь, НҮБ-ын Аюулгүйн зөвлөлөөс баталсан үй олноор хөнөөх зэвсэг бүтээхэд ашиглаж болох бараа бүтээгдэхүүн, эд зүйлсэд хяналт тавих асуудлаарх 1540 тогтоолыг үндэсний түвшинд хэрэгжүүлэх, цөмийн, цацраг идэвхт бусад материалыг хууль бусаар наймаалахаас урьдчилан сэргийлэхэд анхаарч, Монгол Улсад цөмийн, цацраг идэвхт материалын экспорт, импортыг хянах техникийн чадавхийг бэхжүүлэх чиглэлээр 10 сая орчим ам.долларын өртөг бүхий төслийг амжилттай хэрэгжүүлсэн. Эдүгээ Замын-Үүд, Алтанбулаг, Сүхбаатар, Буянт-Ухаа, Цагааннуур, Боршоо, Булган зэрэг 10 гаруй хилийн боомтод цацрагийн идэвхжил илрүүлэгч тоног төхөөрөмж суурилуулаад байна.

Монгол Улс цөмийн эрчим хүчийг энхийн зорилгоор, түүний дотор хүн амын эрүүл мэнд, хүнс хөдөө аж ахуй, мал эмнэлэг, байгаль орчны салбарт ашиглах чиглэлээр Олон улсын атомын энергийн агентлаг(ОУАЭА)-тай хамтын ажиллагаагаа улам бүр өргөжүүлж байна. Тухайлбал, Монгол Улсыг хорт хавдартай тэмцэх Ази бүсийн жишиг төв болгох, хорт хавдартай тэмцэх, сэргийлэх, хянах үндэсний хөтөлбөрийг ОУАЭА-ийн дэмжлэгтэйгээр хэрэгжүүлэх, орчин үеийн технологи, техник хэрэгсэл, тоног төхөөрөмжийг нэвтрүүлэх чиглэлээр бодит үр дүнтэй ажиллаж байна.

ОУАЭА-ийн Техникийн хамтын ажиллагааны хөтөлбөр (ТХАХ)-ийн хүрээнд авч буй тусламж нэмэгдэж байгаа. 2009-2011 оны орны хөтөлбөрийн хүрээнд "Агаарын бохирдлыг хянах лаборатор байгуулах” “Монголын эрдсийн нөөцийг тодорхойлох цөмийн аналитик аргыг шинэчлэх”, “Үхэр, тэмээ, сарлагийн ашиг шимийг сайжруулах болон нөхөн үйлдвэрлэлийн менежмент”, ”Малын халдварт өвчний оношлогоо, сэргээлтийг сайжруулж, оношлогоо бэлдмэлийг үйлдвэрлэх”, “Хил дамнасан малын халдварт өвчнийг оношлох, урьдчилан сэргийлэх бэлдмэлийн тогтвортой үйлдвэрлэлийг дэмжих", "Хүнсний хангамжийг сайжруулах зорилгоор хөрсний элэгдлийг багасгах, үржил шимийг хадгалах стратегийг боловсруулах", "Туяа эмчилгээний үйлчилгээ болон чанарын хяналтыг сайжруулах", “Монгол Улсад туяа эмчилгээний цацрагийн хамгаалалтын аюулгүйн чанарын систем болон шинэ технологи хөгжүүлэх" зэрэг 10 гаруй төсөл, хөтөлбөр тодорхой үр дүнтэй хэрэгжиж байна.

Монгол Улс далайд гарцгүй орны асуудлаар НҮБ-ын хүрээнд идэвхтэй үйл ажиллагаа явуулж ирсэн. 2006 онд болсон Далайд гарцгүй хөгжиж буй орнуудын дээд хэмжээний уулзалтын үеэр манай улс Далайд гарцгүй хөгжиж буй орнуудын олон улсын судалгааны төвийг Улаанбаатар хотноо байгуулах санаачлагыг дэвшүүлж олон улсын хамтын 
нийгэмлэгийн дэмжлэгийг авсан юм. Судалгааны төвийг Улаанбаатарт байгуулах асуудлыг НҮБ-ын Ерөнхий нарийн бичгийн дарга сайшаан дэмжиж, манай улсад 2009 онд айлчлах үеэрээ судалгааний төвийг нээж байсан. Энэ нь далайд гарцгүй хөгжиж буй орнуудад тулгарч буй бэрхшээлийг шийдвэрлэх чиглэлээр НҮБ-аас явуулж буй үйл ажиллагаанд Монгол Улс тэргүүлэх үүрэгтэйгээр оролцож байгааг нотолсон. Нөгөөтэйгүүр, энэ нь Монголд байгуулагдаж буй олон улсын засгийн газар хоорондын анхны байгууллага болж байгаагаараа онцгой ач холбогдолтой юм.

Монгол Улс нийгмийн хөгжлийн зорилтуудыг шийдвэрлэхэд чиглэсэн ажлыг эрчимжүүлэх үҮднээс Бичигтэн болох НҮБ-ын 10 жил, нийгмийн хөгжилд хоршооллын гүйцэтгэх үүрэг, хөдөөгийн эмэгтэйчүүдийн аж байдлыг сайжруулах зэрэг асуудлаар тогтоолын төслийг санаачилж НҮБ-ын Ерөнхий Ассамблейн чуулганаар батлуулж ирсэн. Мөн 2012 оныг “Хоршооллын олон улсын жил” болгон зарлах санаачлагыг дэвшүүлж, Ерөнхий Ассамблейн чуулганаар тогтоол батлуулсан нь хөдөө аж ахуйн салбарт хөрөнгө оруулалтыг нэмэгдүүлэх, жижиг, дунд бизнесийг эрчимжүүлэхэд чухал гэж үздэг.

Монгол, ЮНЕСКО-гийн харилцаа, хамтын ажиллагааг өнгөрсөн 50 орчим жилийн хугацаанд агуулгаар баяжуулан үр дүнтэй ажиллаж байна. Монгол Улсын соёлын өвийг бүртгүүлэх чиглэлээр үр дүнтэй ажиллаж Увс нуурын ай сав газрыг 2003 онд, Орхоны хөндийн соёлын дурсгалт газрыг 2004 онд, Монгол Алтайн нурууны хадны зургийн цогцолборыг 2011 онд Дэлхийн байгалийн болон Соёлын өвийн жагсаалтад тус тус бүртгүүлээд байна. Түүнчлэн морин хуур хөгжмийн уламжлалт урлаг, монгол ардын уртын дуу, монгол үндэстний баяр - Наадам, монгол үндэстний хөөмэйн урлаг, бүргэдийн ан буюу шувуучлахуй урлаг, монгол тууль, монгол ардын бүжгийн урлаг-бий биелгээ, монгол цуур хөгжмийн уламжлалт урлагийг ЮНЕСКО-гийн Биет бус соёлын өвийн жагсаалтад бүртгүүлээд байна. Мөн “Лу.Алтан товч” болон “Монгол Шунхан Данжуур”ыг Дэлхийн Баримтат өвийн бүртгэлт оруулаад байна.

ЮНЕСКО-той өрнүүлж буй хамтын ажиллагааны нэг чухал чиглэл нь манай улсаас санаачлан авч явдаг “Бүх нийтээр бичигтэн болох”, “Бичигтэн болох НҮБ-ын 10 жил”-ийн асуудлаарх НҮБ-ын Ерөнхий Ассамблейн чуулганы шийдвэрийн хэрэгжилтийг хангах явдал мөн.

НҮБ-ын Ерөнхий Ассамблейн 64 дүгээр чуулганаар батлуулсан «Бичигтэн болох НҮБ-ын 10 жил» тогтоолд НҮБ-ын гишүүн 137 улс хамтран зохиогчоор орсон нь манай улсаас дэвшүүлсэн санаачлагыг олон улсын түвшинд хэрхэн үнэлж буйн тод илрэл мөн гэж үзэж 
байна. Уг тогтоолд бүх нийтээр бичигтэн болох зорилтыг хэрэгжүүлэх, 2012 оноос хойш баримтлах стратегиа тодорхойлох чиглэлд анхаарч ажиллахыг НҮБ-ын гишүүн орон, олон улсын холбогдох байгууллага, хандивлагч орон, хувийн хэвшлийнхэн, иргэний нийгэмлэгт уриалсан нь боловсролын чиглэлээрх олон улсын хамтын нийгэмлэгийн үйл ажиллагаа, ЮНЕСКО-оос дэвшүүлж буй санал санаачлалыг дэмжиж хамтран ажиллах, манай улс бодит хувь нэмрээ оруулах чухал ач холбогдолтой байв.

Монгол Улс НҮБ-ын сонгуульт байгууллагуудад гишүүнээр сонгогдон ажиллах чиглэлд багагүй чармайлт гарган ажилладаг. Одоогийн байдлаар НҮБ-ын Эдийн засаг, нийгмийн зөвлөл, ЮНЕСКО-ийн Гүйцэтгэх зөвлөл, Дэлхийн эрүүл мэндийн байгууллагын Гүйцэтгэх зөвлөл, Тогтвортой хөгжлийн комисс, Статистикийн комисс, Эмэгтэйчүүдийн аж байдлын комисс, Нийгмийн хөгжлийн комисс тус тус сонгогдон ажиллаж байна.

Түүнчлэн манай улс Ерөнхий Ассамблейн 65 дугаар чуулганы 2 дугаар хорооны даргаар сонгогдон ажилласан. Чингэхдээ НҮБ-ын шинэчлэлийн асуудлыг урагшлуулах зорилтын хүрээнд Ерөнхий Ассамлейн үйл ажиллагааг, тухайлбал Хоёрдугаар хорооны ажлыг эрчимжүүлэх чиглэлээр шийдвэр гаргуулах асуудлыг санаачлан сүүлийн 10-аад жил гацаанд байсан асуудлыг гишүүн орнуудтай идэвхтэй яриа хэлэлцээ хийсний дүнд нийтийн зөвшилцөлд хүргэж шийдвэрлүүлсэн. Үүнийг НҮБ-ын өөрчлөлт, шинэчлэлийн асуудлыг урагшлуулахад чиглэсэн олон улсын хамтын нийгэмлэгийн хүч чармайлтад Монгол Улс бодитой хувь нэмэр оруулсан гэж Ерөнхий Ассамблейн 65 дугаар чуулганаас дүгнэсэн.

Өнгөрсөн 50 жилийн хугацаанд олсон амжилтаа бататгаж, Монгол НҮБ-ын хамтын ажиллагааг агуулгаар улам бүр, үр дүнтэй баяжуулан өргөжүүлэх нь бидний үүрэг мөн. Иймээс цаашид тавьж буй зорилт, авч хэрэгжүүлэхээр төлөвлөн зорьж буй зарим арга хэмжээний талаар энд дурдах нь зүйтэй болов уу.

\section{Цаашдын зорилтын талаар}

1. Монгол Улс НҮБ-ын Аюулгүйн Зөвлөлийн байнгын бус гишүүний 2022 оны сонгуульд нэрээ дэвшүүлэх шийдвэрийг Засгийн газраас энэ 7 дугаар сард гаргаж, энэ тухайгаа НҮБ-д албан ёсоор мэдэгдээд байна. 
Манай улс 1961 онд НҮБ-д элсэнээс хойш Аюулгүйн Зөвлөлийн гишүүнээр сонгогдон ажиллаж байгаагүй. Өмнө нь 3 удаа нэрээ дэвшүүлэн ажиллаж байсан хэдий ч тодорхой шалтгааны улмаас нэг бус удаа нэрээ татаж байсан.

1976 онд нэрээ дэвшүүлсэн боловч Энэтхэгийн хүсэлтээр нэрээ татсан. 1984 оны сонгуульд Тайланд Улстай өрсөлдсөн боловч дөрвөн удаагийн санал хураалтын дараа ялагдсан (Монгол 49, Тайланд 106 санал тус тус авсан).

НҮБ-ын Аюулгүйн Зөвлөлийн байнгын бус гишүүний сонгуульд бэлтгэж байсан туршлага, уг сонгуульд манай улс нэрээ дэвшүүлэх аваас тулгарах давуу болон сул тал, Аюулгүйн Зөвлөлийн гишүүний өмнө тавигдах шаардлагыг хангахад бэлтгэх хугацаа, шаардагдах боловсон хүчний чадавх, хөрөнгө санхүҮ, сонгуульд ялах таатай нөхцлийг бүрдүүлэх зэргийг сайтар нягталж, холбогдох судалгаа, тооцоо, дүгнэлтийг хийн ажиллаж байна. Тухайлбал,

• $\quad$ Өөрийн харъяалагдах газар зүйн бүлгийн 100 хувийн дэмжлэгийг авч, харъяалагдах бүлгээсээ өрсөлдөгчгүй сонгуульд оролцох нь амжилт олох нэн чухал үндэслэл мөн. Тиймээс ч тодорхой судалгаа хийсний үндсэн дээр 2022 оныг сонгосон. Нөгөөтэйгүүр, улс төрийн хувьд чухал ач холбогдолтой хэдий ч нэн хариуцлагатай сонгуульд сайтар бэлтгэл хангах хангалттай цаг хугацаа мөн гэж үзэж байгаа.

• НҮБ-ын Аюулгүйн Зөвлөлийн гишүүнээр сонгогдоход уг сонгуульд нэр дэвшигч орны олон улсын энх тайван, аюулгүй байдлыг сахиулах хийгээд байгууллагын бусад зорилтыг хэрэгжүүлэх үйлсэд оруулж буй хувь нэмрийн жин, нэр хүнд чухал үндэслэл болдог. Тиймээс НҮБ-ын хүрээнд Монгол Улсын нэр хүндийг өсгөх, байр суурийг бэхжүүлэх чиглэлээр тодорхой ажлыг үе шаттайгаар хэрэгжүүлэх шаардлагатай байгаа.

Тухайлбал:

НҮБ-ын энхийн сахиулах, энхийг цогцлоох үйл ажиллагаан дахь оролцоогоо улам бүр нэмэгдүүлэхийг зорьж байна. Энхийг сахиулах ажиллагаанд зэвсэгт хүчний цэргийн баг илгээж, гүйцэтгэх үүргийн цар хүрээг тэлэхийн зэрэгцээ иргэний цагдаа, улс төрийн ажиглагчаа оролцуулж, хүмүүнлэгийн үйл ажиллагаанд оролцохыг зорьж байна.

НҮБ болон олон улсын хамтын нийгэмлэгийн өмнө тулгамдсан томоохон асуудлыг шийдвэрлэхэд бодит хувь нэмрээ оруулж, тодорхой асуудлаар гаргах санал санаачлагаа улам бүр нэмэгдүүлэх нь зүйтэй гэж үздэг. Чингэхдээ өөрийн улсын эрчимтэй, тогтвортой 
эдийн засгийн хөгжлийг урагшлуулахад чиглэсэн асуудалд онцгойлон анхаарахын зэрэгцээ биднээс гаргасан санаачилга нь дэлхийн улс түмний нийтийн эрх ашигт нийцэж, өөрийн улсын хөгжилд төдийгүй бусад улс орны хөгжилд бодит үр дүнгээ өгдөг байх нь чухал юм. Иймээс Ардчиллын боловсролыг төлөвшүүлэх асуудлыг сонгон авч НҮБ-ын гишүүн орнуудтай яриа хэлэлцээ хийж ирэх онд Ерөнхий Ассамблейн чуулганаар тогтоол санаачлан батлуулахаар төлөвлөн ажиллаж байгаа.

НҮБ олон улсын хамтын нийгэмлэгийн үйл ажиллагаанд оролцоогоо улам бүр идэвхжүүлж, дуу хоолойгоо сонсгох, саналаа нэмэрлэх нь чухал гэж үзэж НҮБ-ын сонгуульт байгууллагад гишүүнээр ажиллах ажлаа бэхжүүлэх шаардлагатай байгаа. Тиймээс ч өмнө нь гол төлөв эдийн засаг, нийгэм, байгаль орчны асуудлаарх гүйцэтгэх зөвлөл, комиссын гишүүнээр ажиллаж байсан бол одоо цар хүрээгээ тэлж ардчилал, хүний эрхийн чиглэлд анхаарч ойрын хугацаанд НҮБ-ын Хүний эрхийн зөвлөлийн сонгуульд оролцохоор төлөвлөж байгаа.

• НҮБ-ын томоохон сонгуульд оролцох, гишүүнээр нь сонгогдсоны дараа тодорхой зорилготой, үр дүнтэй идэвхтэй ажиллахад манай улсын боловсон хүчний чадавх чансаа, ур чадвар нэн чухал. Жишээ нь Аюулгүйн Зөвлөлийн гишүүнээр ажиллахад Монгол Улсын төдийгүй Азийн орнуудыг төлөөлөн байр сууриа оновчтой, түргэн шуурхай боловсруулж, шийдвэр гаргах шаардлага тавигдана. Үүний тулд олон улсын энх тайван, аюулгүй байдлын асуудлуудаар бодитой мэдээллийг газар дээрээс нь шуурхай авах өөрийн ДТГ-дын сүлжээтэй байх, бодит мэдээлэлд үндэслэж үнэлгээ дүгнэлт хийх, бусад улстай нууц, ил тод яриа хэлэлцээ хийх зэргээр дипломат ур чадвар, чадавх өндөр байх нь зайлшгүйгээр шаардагдана. Тиймээс боловсон хүчнээ бэхжүүлэхэд онцгойлон анхаарч байгаа.

• Нөгөөтэйгүр, НҮБ болон олон улсын бусад байгууллагын нарийн бичгийн дарга нарын газарт ажиллах монгол иргэдийн тоог нэмэгдүүлэхэд мөн чухалчлан анхаарч түүнийг хэрэгжүүлэхдээ тодорхой бодлого, замын зураг гарган ажиллахаар төлөвлөж байгаа.

Дээр дурдсан зүйлийг хэрэгжүүлэхэд нилээдгүй хүч чармайлт гаргаж ажиллах нь бидний Үүрэг. Гэхдээ өмнөө тавих зорилт, тэдгээрийг хэрхэн үр дүнтэй хэрэгжүүлэх талаар Та бүхний санаа оноо нэн чухал. Иймээс туршлага ихээр хуримтлуулсан Та бүхэн бидэнд үнэтэй зөвлөгөө өгч, саналаа хуваалцана гэдэгт итгэлтэй байна. 
